\title{
KUALITAS PELAYANAN PUBLIK DI KANTOR DESA PARIGI KECAMATAN TINGGIMONCONG KABUPATEN GOWA
}

\author{
Musdalipa $^{1}$, Anwar Parawangi ${ }^{2}$, Ihyani Malik ${ }^{3}$ \\ ${ }^{1}$ Jurusan Ilmu Administrasi Negara Unismuh Makassar \\ ${ }^{2}$ Jurusan Ilmu Pemerintahan Negara Unismuh Makassar \\ ${ }^{3}$ Jurusan Ilmu Administrasi Negara Unismuh Makassar
}

\begin{abstract}
The aim of the study is to find out how the quality of Public Service at the Parigi village office, District Tinggimoncong, Gowa. The research method used was a qualitative descriptive study. There were 16 informants and the data were collected through interview, observation, and documentation. The technique of data analysis was conducted through the stages of data reduction, data presentation and data verification. The results of the research showed that generallythe quality of public services at the village office of Parigi, District Tinggimoncong,Gowabased on the five indicators, namely, tangible, reliability, responsiveness, assurance, and empathy was still less qualified, as well as the apparatus of Parigi village should further improve theservice quality again to increase the ability and motivation, and the most important thing is discipline
\end{abstract}

Keywords: quality, service

\begin{abstract}
ABSTRAK
Penelitian ini bertujuan untuk mengetahui bagaimana Kualitas Pelayanan Publik Di Kantor Desa Parigi Kecamatan Tinggi moncong Kabupaten Gowa. Metode penelitian yang digunakan adalah jenis penelitian deskriptif kualitatif. Informan berjumlah 16 orang dengan menggunakan teknik pengumpulan data melalui wawancara, observasi dan dokumentasi. Teknik analisis data penelitian melalui tahapan reduksi data, penyajian data, dan verifikasi data. Hasil penelitian ini menunjukkan bahwa umumnya kualitas pelayanan publik di Kantor Desa Parigi Kecamatan Tinggi Moncong Kabupaten Gowa yang di lihat dari lima indicator yaitu, berwujud, kehandalan, ketanggapan, jaminan, dan empati masih kurang berkualitas. Begitupun aparatur Desa Parigi harus lebih meningkatkan kualitas pelayanananya lagi dengan meningkatkan kemampuan dan motivasi yang paling utama kedisiplinan.
\end{abstract}

Kata Kunci : Kualitas, Pelayanan 


\section{PENDAHULUAN}

Kualitas pelayanan publik merupakan salah satu agenda reformasi birokrasi, yang bertitik tolak dari kenyataan buruk kondisi faktual kualitas pelayanan publik yang sebagian besar di tentukan oleh kualitas sikap dan karakter aparatur pemerintah yang tidak terpuji, korup, dan tidak bertanggung jawab.

Pemerintah mempunyai peranan penting untuk menyediakan layanan publik yang prima bagi semua penduduknya sesuai yang telah diamanatkan dalam UndangUndang. Dalam pasal 1 UndangUndang Nomor 25 Tahun 2009 tentang pelayanan publik disebutkan pengertian pelayanan publik sebagai berikut :"Pelayanan publik adalah kegiatan atau rangkaian kegiatan dalam rangkapemenuhan kebutuhan pelayanan sesuai dengan peraturan perundang-undangan bagi setiap warga Negara dan penduduk atas barang, jasa dan atau pelayanan administratif yang disediakan oleh penyelenggara pelayanan publik".

Pelayanan publik merupakan suatu usaha yang dilakukan kelompok atau seseorang birokrasi untuk memberikan bantuan kepada masyarakat dalam rangka mencapai suatu tujuan tertentu. Salah satu dari pelaksanaan pelayanan publik yaitu pelayanan administrasi kependudukan yang berada di suatu pemerintahan.

Administrasi kependudukan adalah rangkaian kegiatan penataan dan penertiban dalam penertiban dokumen dan data kependudukan melalui pendaftaran penduduk, pencatatan sipil, pengelolaan informasi administrasi kependudukan serta pendayagunaan hasilnya untuk pelayanan publik dan membangun sektor lain.

Berbicara tentang pelayanan yang diberikan pemerintah tentunya tidak terlepas dari pelayanan pemerintah pada sektor publik karena umumnya pelayanan yang diberikan pemerintah itu dalam bidang/sektor yang menyangkut kepentingan umum seperti pengurusan KTP, akta kelahiran, kartu keluarga, dan lain-lain.

Pelayanan publik perlu memperhatikan kebutuhan yang diinginkan dan dibutuhkan pelanggan. Kebutuhan pelanggan dapat terpenuhi dengan baik. 
Sementara itu Sinambella (2008:5) memberikan pengertian pelayanan publik sebagai berikut :

Setiap kegiatan yang dilakukan oleh pemerintah terhadap sejumlah manusia yang memiliki setiap kegiatan yang menguntungkan dalam suatu kumpulan atau kesatuan, dan menawarkan kepuasan meskipun hasilnya tidak terikat pada suatu produk secara fisik.

Adapun

pelayanan publik pengertian kurniayan (2005 : 4) adalah "pemberian layanan (melayani) keperluan orang atau masyarakat yang mempunyai kepentingan pada organisasi itu sesuai dengan aturan pokok dan tatacara yang ditetapkan".

Pelayanan publik merupakan tanggung jawab pemerintah dan dilaksanakan oleh instansi pemerintah, baik itu di pusat, di daerah, dan di lingkungan Badan Usaha Milik Negara. Pelayanan publik berbentuk pelayanan barang publik maupun pelayanan jasa yang baik yang diinginkan oleh semua masyarakat. Dewasa ini masyarakat yang kita ketahui, masyarakat juga semakin terbuka dalam memberikan kritik bagi pelayanan public.

Abidin (2010, hal: 71) mengatakan bahwa pelayanan publik yang berkualitas bukan hanya mengacu pada pelayanan itu semata, juga menekankan pada proses penyelenggaraan atau penditribusian pelayanan itu sendiri hingga ke tangan masyarakat sebagai konsumer.

Surjadi (2012 : 9) dalam penyelenggaraan pelayanan publik dilakukan berdasarkan pada asasasas umum kepemerintahan yang baik, meliputi : kepastian hukum, transparansi, daya tanggap, berkeadilan, efektif dan efesien, tanggung jawab, akuntabilitas, dan tidak menyalahgunakan kewenangan.

Pelayanan publik adalah pemenuhan keinginan dan kebutuhan masyarakat oleh penyelenggara Negara. Negara didirikan oleh publik (masyarakat) tentu saja dengan tujuan agar dapat meningkatkan kesejahteraan masyarkat. Pada hakikatnya Negara dalam hal ini pemerintah (birokrat) haruslah dapat memenuhi kebutuhan masyarakat. Kebutuhan dalam hal ini 
bukanklah kebutuhan secara pelaksanaan ketentuan peraturan individual akan tetapi bergadai kebutuhan yang sesungguhnya per4undang-undangan.

Kualitas adalah memenuhi diharapkan oleh masyarakat, misalnya kebutuhan akan kesehatan, pendidikan, dan lain-lain.

Kegiatan pelayanan dalam suatu organisasi memiliki peran penting dan strategi, terutama bagi organisasi yang berorientasi pada pelayanan jasa. Hal itu tercermin pada pengertian pelayanan yang dikemukakan oleh Moenir (2000 : 12) sebagai berikut :

Pelayanan adalah setiap kegiatan oleh pihak lain ditujukan untuk memenuhi kepentingan orang banyak, pelayanan ini sifatnya selalu kolektif, sebab pelayanan kepentingan itu masih termasuk dalam rangka pemenuhan hak dan kebutuhan bersama yang telah diatur termasuk dalam pengertian pelayanan.

Segala bentuk pelayanan umum yang dilaksanakan oleh instansi pemerintah di pusat, di daerah, dan di Lingkungan Badan Usaha Milik Negara atau Daerah dalam bentuk barang dan jasa, baik dalam rangka upaya pemenuhan atau sama dengan persyaratannya, maka suatu produk atau jasa dikatakan tidak memuaskan. Persyaratan itu sendiri dapat berubah sesuai dengan keinginan pelanggan, kebutuhan organisasi pemasok dan sumber pemerintah, teknologi serta pasar atau pesaing”.

Surjadi (2012 :286) menyatakan bahwa pelayanan pemerintah daerah merupakan tugas dan fungsi utama pemerintah daerah. Hal ini berkaitan dengan fungsi dan tugas utama pemerintah akan dapat mewujudkan tujuan Negara yaitu menciptakan kesejahteraan masyarakat. Pelayanan kepada masyarakat tersebut terintegrasi dalam penyelenggaraan pemerintah dan pembangunan.

Keputusan Menteri Negara Pendayagunaan Aparatur Nomor 81 Tahun 1993 tentang Pedoman Tata Laksana Pelayanan adalah segala bentuk pelayanan umum yang dilaksanakan oleh instansi pemerintahan di pusat, di daerah dalam bentuk barang dan jasa, baik dalam rangka upaya pemenuhan 
pelaksanaan ketentuan peraturan perundang-undangan.

Memahami pengertian pelayanan seperti yang termuat dalam Surat Keputusan Negara Pendayagunaan Aparatur Negara No. 81 / 1993, maka dapat dipahami bahwa instansi pemerintahan yang berorientasi pada pelayanan umum harus memberikan pelayanan prima kepada yang dilayani, artinya pelayanan yang memuaskan adalah suatu tanggung jawab (kewajiban) pihak pemberi pelayanan dan merupakan Hak dari pihak penerima layanan yang dibenarkan oleh ketentuan hukum.

Kantor desa sebagai suatu instansi pemerintah yang salah satu bidang tugasnya menangani pelayanan publik, pada dasarnya mengembangkan dua fungsi utama dalam hal operasionalnya yaitu, fungsi pelayanan teknis dan pelayanan administrasi.

Menurut Kontler dalam Sampara Lukman (2002 : 8) pelayanan adalah setiap kegiatan yang menguntungkan dalam suatu kumpulan atau kesatuan, dan menawarkan kepuasan meskipun hasilnya tidak terikat padaa suatu produk secara fisik. Selanjutnya Sampara berpendapat, pelayanan adalah suatu kegiatan atau urutan kegiatan yang terjadi dalam interaksi langsung antar seseorang dengan orang lain atau mesin secara fisi, dan menyediakan kepuasan pelanggan.

Sementara dalam kamus

Besar Bahasa Indonesia dijelaskan pelayanan sebagai hal, cara, atau hasil pekerjaan melayani, sedangkan melayani adalah menyuguhi (orang) dengan makanan atau minuman menyediakan keperluan orang, mengiyakan menerima, menggunakan.

Menurut Lijan , dkk ( 2014 : 5) pelayanan publik adalah pemenuhan keinginan dan kebutuhan masyarakat pada hakikatnya Negara dalam hal ini pemerintah (birokrat) haruslah dapat memenuhi kebutuhan masyarakat.

Defenisi kualitas yang dikemukakan oleh Juran, Jasep M (dalam Tjiptono, Fandy, 2000 : 53) mendefinisikan kualitas dengan menyatakan bahwa Kualitas sebagai cocok atau sesuai untuk digunakan, yang mengandung pengertian bahwa suatu produk atau jasa harus dapat 
memenuhi apa yang diharapkan oleh pemakainya. Sedangkan Crosby, Philip B (dalam Nasution, 2005 : 37)mengemukakan bahwa

Kualitas adalah memenuhi atau sama dengan persyaratannya, maka suatu produk atau jasa dikatakan tidak memuaskan. Persyaratan itu sendiri dapat berubah sesuai dengan keinginan pelanggan, kebutuhan organisasi pemasok dan sumber pemeruntah, teknologi serta pasar atau pesaing.

Menurut Zethhaml, parasuraman \& Berry (dalam Hardiyansyah (2011 : 46) untuk mengetahui kualitas pelayanan yang dirasakan secara nyata oleh konsumen,ada indikator kualitas pelayanan yang terletak pada lima dimensi kualitas pelayanan yang tercermin dari beberapa tahapan-tahapan yang akan di lalaui yaitu, berwujud, kehandalan, ketanggapan, jaminan, dan empati.

Istilah pelayanan publik disebut juga dengan istilah pelayanan sesuai pelayanan kepada orang (masyarakat) banyak, pelayanan sosia, pelayanan umum, dan pelayanan prima. Disisi lain salah satu isu yang sangat penting dalam hal ini terjadi karena tuntutan masyarakat terhadap kualitas pelayanan yang semakin besar sementara praktek penyelenggara pelayanan yang tidak mengalami perubahan yang berarti, masyarakat setiap waktu menuntut pelayanan publik yang berkualitas meskipun tuntutan tersebut sering tidak sesuai.

\section{METODE PENELITIAN}

Penelitian ini menggunakan jenis penelitian deskriptif kualitatif yaitu suatu penelitian dimana peneliti berusaha mendeskripsikan atau menggambarkan tentang Kualitas Pelayanan Publik Dikantor Desa Parigi Kecamatan Tinggimoncong Kabupaten Gowa, serta Faktor Pendukung dan Penghambat Kualitas Pelayanan Publik Di Kantor Desa Parigi Kecamatan Tinggimoncong Kabupaten Gowa. Penelitian ini berlangsung selama dua bulan setelah seminar proposal. Peneliti melakukan pengumpulan data primer berupa wawancara dan pengamatan langsung terhadap objek yang diteliti dengan informan maupun melalui pengamatan langsung dan melakukan kajian data sekunder berupa data 
seperti profil desa, buku bacaan dan lain sebagainya yang berkaitan dengan Kualitas Pelayanan Publik Di Kantor Desa Parigi Kecamatan Tinggimoncong Kabupaten Gowa, dengan informan sebanyak 16 orang yang terdiri dari kepala desa, staf desa, dan masyarakat.

Teknik pengumpulan data yang merupakan langkah yang sangat penting dalam penelitian. Pengumpulan data adalah prosedur yang sistematik dan standar untuk memperoleh data yang diperlukan melalui observasi, dokumentasi, wawancara dengan masyarakat dan aparatur di Kantor Desa Parigi Kecamatan Tinggimoncong Kabupaten Gowa.

Teknik analisis data dalam penelitian kualitatif, dilakukan pada saat pengumpulan data yang berlangsung, dan setelah selesai pengumpulan data dalam periode tertentu dengan tahap reduksi data yang diperoleh dari lapangan, dan tahap penarikan kesimpulan dan verivikasi data, yang mendukung tahap pengumpulan data.

pengabsahan data yang terdiri

dari Trianggulasi Sumber yang membandingkan dan mengecek balik derajat kepercayaan suatu informasi yang diperoleh melalui waktu dan alat yang berada dalam penelitian kualitatif. Trianggulasi Teknik data yang di dari Desa Parigi Kecamatan Tinggimoncong Kabupaten Gowa

\section{HASIL DAN PEMBAHASAN}

Kualitas pelayanan publik merupakan salah satu agenda reformasi birokrasi pemerintahan yang bertitik tolak dari kenyataan buruk kondisi faktual kualitas pelayanan publik yang sebagian besar ditentukan oleh kualitas sikap dan karakter aparatur pemerintah yang terpuji, korup, dan tidak bertanggung jawab, sehingga membuat masyarakat tidak puas akan pelayanan yang diberikan oleh aparat Peningkatan kualitas pelayanan publik merupakan salah satu isu yang sangat penting untuk aparat-aparat di pemerintahan,yang juga berada di kantor desa.

Dalam hal ini terjadi karena disatu sisi tuntutan masyarakatmasyarakat terhadap kualitas pelayanan juga semakin besar dan 
semakin banyak sementara praktek penyelenggaraan pelayanan tidak mengalami perubahan yang berarti. Masyarakat yang setiap waktu menuntut pelayanan publik yang berkualitas, meskipun tuntutan tersebut sering tidak sesuai dengan harapan karena pelayanan publik yang terjadi selama ini masih berbelit-belit, mahal, dan melelahkan.

Seiring dengan berjalannya kebijakan otonomi daerah, aparat birokrasi pemerintahan di daerah dapat mengelola dan menyelenggarakan pelayanan publik yang lebih peduli dengan kebutuhan masyarakat daerahnya. Terdapat konsep yang mendasar dalam hal mengelola urusan yang mengatur pemerintah local ini yakni adanya prakarsa sendiri berdasarkan pada aspirasi masyarakat setempat demi mencapai kesejahteraan mereka. Namun pada kenyataan penyelenggaraan pelayanan publik yang dilakukan oleh pemerintah masih dihadapkan pada pelayanan yang belum efektif dan efesien serta kualitas sumber daya manusia yang belum memadai.
Hal ini terlihat dari masih banyaknya pengaduan dari masyarakat baik secara langsung maupun tidak langsung, seperti melalui media massa yang menuntut peningkatan kualitas pelayanan publik.

Pelayanan publik merupakan tanggung jawab pemerintah dan dilaksanakan oleh istansi pemerintah, baik itu di pusat, daerah, dan di Lingkungan Badan Usaha Milik Negara. Peleyanan public berbentuk pelayanan barang publik maupun pelayanan jasa., oleh sebab itu subtansi administrasi sangat berperan dalam mengatur dan mengarahkan seluruh kegiatan organisasi pelayanan dalam mencapai tujuan.

Salah satu keluhan yang sering terjadi dan terdengar dari masyarakat yang berhubungan dengan aparatur pemerintah adalah selain berbelitbelit akibat birokrasi yang kaku, perilaku oknum aparatur yang kadang kala kurang bersahabat, juga kinerja pegawai dalam memberikan pelayanan dalam hal ini ketepatan waktu dalam memberikan pelayanan, kualitas yang masih sangat rendah untuk masyarakat. 
Tangibel (berwujud) merupakan indikator kualitas pelayanan publik yang dapat dilihat dari sarana fisik perkantoran, Komputerisasi, ruang tunggu, dan tempat informasi. Kualitas pelayanan publik di kantor Desa Parigi Kecamatan Tinggimoncong dari segi tangibel sudah di nilai oleh sebagian besar masyarakat di Desa Parigi Kecamatan Tinggimoncong Kabupaten Gowa. Kualitas pelayanan juga tergantung pada kondisi fisik kantor dan fasilitas pendukung dalam pelayanan sehingga masyarakat atau kostumer dapat mendapat kemudahan dan Kenyamanan dalam proses pelayanan, kualitas pelayanan juga tergantung pada kondisi fisik kantor dan fasilitas pendukung dalam pelayanan sehingga masyarakat atau kostumer dapat mendapatkan kemudahan dan kenyamanan dalam proses pelayanan di Kantor Desa Parigi Kecamatan Tinggimoncong Kabupaten Gowa.

Berdasarkan hasil penelitian kualitas pelayanan dari segi tangible di kantor Desa Parigi, penulis menemukan bahwa fasilitas pendukung pelayanan seperti alat komputer masih sangat kurang, keberadaan pegawai yang bertugas di kantor desa tersebut juga masih perlu ditingkatkan kehadirannya.

$$
\text { Realibility (kehandalan) }
$$

merupakan kemampuan kantor desa untuk menyediakan pelayanan yang terpercaya, konsisten dan kesesuaian pelayanan. Hal ini penting mengingat masyarakat membuktikan pembuktian dari janji-janji pelayanan di kantor Desa Parigi Kecamatan Tinggimoncong Kabupaten Gowa. Kehandalan ini dapat kita ukur dari kecermatan petugas melayani, adanya standar pelayanan yang jelas, kemahiran petugas pelayanan dalam menggunakan alat bantu dalam proses pelayanan. Masalh pelayanan yang diterapkan di Kantor Desa Parigi Kecamatan Tinggimoncong Kabupaten Gowa biasanya dirapatkan dengan aparat-aparat desa, namun penyampaianpenyampaian yang masih kurang jelas kepada masyarakat inilah yang menyebabkan standar pelayanan yang masih kurang jelas, dan bagaimana kemampuan petugas dalam menggunakan alat bantu pelayanan (komputer). 
Persyaratan kehandalan yang merupakan unsure pelayanan yang baik, masih belum dipenuhi oleh pelayanan di Kantor Desa Parigi Kecamatan Tinggimoncong Kabupaten Gowa, hal ini dapat kita ketahui dari masih adanya keluhan masyarakat tentang kesalahan pengetikan pada dokumen resmi mereka, sebagian besar petugas pelayanan yang kurang mahir menggunakan computer, dan tidak disiplin waktu dalam memberikan pelayanan.

Berdasarkan hasil wawancara tentang kehandalan pegawai kantor dalam disiplin waktu untuk hadir di kantor tepat waktu. Kualitas pelayanan juga dapat dilihat dari kedisiplinan petugas pelayanan dalam memberikan pelayanan tepat waktu dengan hadir di kantor pada jam kerja yang telah ditentukan.

Pengamatan penulis selama lima kali melakukan observasi di kantor Desa Parigi Kecamatan Tinggimoncong Kabupaten Gowa, penulis melihat bahwa hanya ada tiga orang petugas yang hadir di kantor, salah satu diantaranya adalah sekretaris desa yang biasa dating tepat waktu. Hasil penelitian menunjukkan bahwa persyaratan kehandalan yang merupakan unsur pelayanan yang baik, masih belum dipenuhi oleh pelayanan di kantor Desa Parigi Kecamatan Tinggimoncong Kabupaten Gowa.

Hal ini dapat kita ketahui dari masih adanya keluhan masyarakat tentang kesalahan pengetikan pada dokumen resmi mereka, sebagaian besar petugas pelayanan yang kurang mahir menggunakan computer, dan tidak disiplin waktu dalam memberikan pelayanan.

Responsivess (Ketanggapan) merupakan kesanggupan untuk membantu dan menyediakan pelayanan secara cepat dan tepat, serta tanggap terhadap keinginan konsumen serta mendengarkan dan mengatasi keluhan yang diajukan konsumen, untuk mengetahui ketanggapan dalam pelayanan di kantor Desa Parigi Kecamatan Tinggimoncong Kabupaten Gowa, dari beberapa hasil penelitian di jelaskan bahwa kantor desa berupaya memberikan pelayanan yang terbaik, hanya kadang ada warga yang mengajukan layanan tapi tidak 
kooperatif dalam proses pelayanan di kantor Desa Parigi Kecamatan Tinggimoncong Kabupaten Gowa tersebut, sedangkan menurut pendapat petugas lainnya, pelayanan tidak berjalan lancar karena kendala peralatan dan kurangnya petugas pelayanan, di Kantor Desa Parigi Kecamatan Tinggimoncong Kabupaten gowa tapi yang namun pada kenyataannyapun biasanya sikap aparatur desa parigi saat melayani

biasanya tidak menyenangkan dan tidak melayani dengan baik .

Ketanggapan merupakan salah satu syarat dari pelayanan yang baik, tolak ukur ketanggapan dalam proses pelayanan yaitu pelayanan yang merespon setiap pelanggan/pemohon yang ingin mendapatkan pelayanan, petugas melakukan pelayanan yang cepat dan cermat, dengan waktu yang tepat, semua keluhan pelanggan direspon oleh petugas.

Berdasarkan hasil wawancara diatas diperoleh keteranganbahwa tanggapan petugas dalam pelayanan di kantor Desa Parigi Kecamatan Tinggimoncong Kabupaten Gowa, masih kurang memuaskan , masyarakat masih mengeluh soal sikap petugas yang apatis, pelayanan yang lambat dan sikap tidak menyenangkan lainnya.

Kualitas pelayanan dalam arti pelayanan yang cepat bukan hanya bergantung pada petugas pelayanan tapi sikap masyarakat yang kooperatif selama proses pelayanan ikut andil dalam hal ini, seperti yang dikemukakan oleh kutipan wawancara sebelumnya, bahwa terkadang ada warga yang memaksa untuk dberikan pelayanan meski mereka tidak memenuhi persyaratan administrasitif, sementara itu instansi pemberi layanan harus memiliki fasilitas pendukung dalam pelayanan untuk memberikan pelayanan yang cepat, dalam kalimat lain, kualitas pelayanan harus mengandung unsur pemenuhan hak dan kewajiban pemberi dan penerima pelayanan yang diketahui secara jelas oleh masing-masing pihak.

Assurance (jaminan), merupakan salah satu unsur daam pelayanan yang menyangkut kepercayaan masyarakat terhadap pelayanan yang diberikan, jaminan 
yang dimaksud disini jaminan tepat waktu dalam pelayanan dengan kemampuan dan keramahan serta sopan santun aparatur dalam meyakini kepercayaan konsumen, dimana tingkat kepuasan masyarakat dalam pelayanan dengan kemampuan dan keramahan serta sopan santun aparatur desa dalam meyakini kepercayaan konsumen, diman tingkat kepuasan masyarakat, dalam melaksakan pelayanan yang memuaskan, tentunya tak terlepas dari sikap dalam menghadapi pelanggan atau kontak personal.

Hal ini merupakan aspek yang penting dalam menentukan kualitas dalam pemberi pelayannan, untuk mencapai hal ini, maka performance atau penampilan yang baik dan rapi turut mendukung dengan sikap ramah, memperhatikan gairah kerja, sikap siap melayani, tenang dalam bekerja,mengetahui dengan baik pekerjaan bak yang berhubungan dengan tugas unitnya maupun unit lain, mampu berkomunikasi dengan baik dan mampu menangani keluhan masyarakat-masyarakat kepada aparat-aparat desa yang ada di kantor
Berkaitan dengan kondisi di kantor Desa Parigi Kecamatan Tinggimoncong Kabupaten Gowa, hal ini menunjukkan tidak puasnya masyarakat terhadap pelayanan yang diberikan oleh pegawa di kantor desa Parigi namun perlu di ketahui sebab akibat kurang tepatnya waktu peayanan itu terjadi,dan hal ini tergantung pada jenis permasalahan yang dihadapi dan apabila permasalahan yang ditangani memerlukan waktu lebih dari satu hari karena semakin cepat penyelesaian permasalahan yang ada maka dapat dikatakan semakin optimal tingkat efektifitas pelayanan pegawai pada kantor Desa Parigi Kecamatan Tinggimoncong Kabupaten Gowa tidak ada ketepatan harga yang pasti dan jela.

Empaty (empati) setiap pemberian pelayanan harus memiliki rasa empati kepada masyarakat, sikap pemberi layanan yang menunjukkan rasa peduli yang besar kepada kebutuhan penerima layanan, dengan begitu pemberi layanan akan melyani pelanggan dengan sepenuh hati, sebelumnya telah di ketahui bahwa pegawai di kantor Desa Parigi 
Kecamatan Tinggimoncong Kabupaten Gowa seringkali apatis, petugas sringkali tidak merespon keluhan atau permintaan dari masyarakat, tidak sedikit dari petugas-petugas tersebut yang sering datang terlambat, akibatnya pelayanan terlambat dibuka dan waktu pelayanan terasa sangat singkat, sebab masyarakat yang mengajukan pelayanan juga jumlahnya tidak sedikit, akhirnya ada beberapa masyarakat yang tidak dilayani.

Selain itu, salah satu warga desa Parigi menjelaskan bahwa ada perlakuan diskriminatif (membedabedakan) dalam pelayanan di kantor Desa Parigi Kecamatan Tinggimoncong Kabupaten Gowa, diman orang-orang terdekat dari kepala desa akan dilayani denagncepat atau didahulukan dari yang lain.

Berdasarkan situasi tersebut, tentu saja unsur empati belum dimiliki oleh para petugas di kantor Desa Parigi Kecamatan Tinggimoncong Kabupaten Gowa, mengenai sikap sopan santun dan keramahan aparatur di Kantor Desa
Parigi Kecamatan Tinggimoncong dapat kita ambil kesimpulan bahwa tidak semua aparatur desa yang tidak sopan itu semua tergantung dari aparatnya, yang kemungkinan hanya terlalu lelah sehingga terlihat menjadi tidak baik, jika kita bandingkan kondisi ideal tersebut dengan kondisi aktualnya, jelas terlihat jauh berbeda.

Adapun faktor-faktor kualitas pelayanan publik di kantor Desa Parigi Kecamatan Tinggimoncong Kabupaten Gowa , yang dijelaskan dari hasil penelitian, dari factor penghambat kualitas pelayanan publik di kantor Desa Parigi Kecamatan Tinggimoncong Kabupaten Gowa dinilai dari segi kualitas kerja terhadap kebutuhan masyarakat mencakup pada sarana dan prasarana yang juga berpengaruh terhadap kualitas pelayanan di kantor Desa Parigi Kecamatan Tinggimoncong Kabupaten Gowa yang dapat mempersulit dan menghambat saat pelaksanaan pelayanan publik.

Berdasarkan hasil wawancara yang dilakukan peneliti dapat disimpulkan bahwa, sarana dan 
prasarana di kantor Desa Parigi , masih belum memberikan kenyamanan saat bekerja, seperti peralatan komputer dalam memberikan pelayanan cukup kurang untuk itu perlu ada perhatian kepada pimpinan melengkapi dalam menunjang kelancaran pegawai untuk menyelesaikan pekerjaan yang di butuhkan masyarakat.

Masalah ketepatan waktu juga menjadi faktor penghambat kualitas pelayanan, di kantor Desa Parigi Kecamatan Tinggimoncong Kabupaten Gowa , masalah waktu kerja yang belum mencapai yang diharapkan karena dari hasil penelitian memberikan pandangan bahwa dalam ketepatan waktu untuk menyelesaikan pekerjaan seperti, pengurusan surat izin, surat keterangan membutuhkan beberapa waktu yang lama untuk mengurusnya.

Kedisiplinan pegawainyapun masih kurang disiplin terlihat dari kerja yang belum optimal seperti ketidak sesuaian jadwal waktu saat bekerja pegawai masih ada yang pulang belum sesuai jam pulang kantor untuk itu masih perlu diperhatikan.

Faktor yang mendukung kualitas pelayanan publik di kantor Desa Parigi Kecamatan Tinggimoncong Kabpaten Gowa, kemampuan kerja dalam hal mengenai hasil kerja terhadap pengetahuan pegawai di kantor desa, sudah memenuhi tanggup jawabnya, walaupun kebanyakan pegawai masih ada yang belum menguasai alat-alat perlengkapan, seperti komputer yang masih mengharapkan bantuan dari rekan dalam menyelesaikan surat-surat dan dokumen lainnya.

Faktor pendukung dari segi motivasi dalam memberikan pelayanan terhadap tanggung jawab yang diberikan kepada pimpinan, motivasi merupakan serangkaian usaha-usaha dalam rangka memberikan motivasi (dorongan), harapan dari insentif kepada pegawai agar dapat terpenuhi kebutuhannya dan pada akhirnya dapat meningkatkan kualitas pelayanan dan semangat kerja dalam mencapai visi organisasi. 
Dalam menjalankan tugasnya pegawai yang diberi tugas oleh pemimpin, dari hasil tugas dan tanggung jawabnya pimpinan sering memberikan penghargaan dan insentif bagi pegawai yang melaksanakan pekerjaan yang penuh rasa tanggung jawab yang bekerja diluar kerja.

\section{KESIMPULAN}

Berdasarkan uraian pada hasil pembahasan, maka dapat disimpulkan bahwa Kualitas pelayanan publik di Kantor Desa Parigi Kecamatan Tinggimoncong Kabupaten Gowa, penulis dapat menyimpulkan bahwa kualitas pelayanan seperti keterampilan dan pengetahuan masih perlu ditingkat, ketepatan waktu dalam menyelesaikan pekerjaan yang diberikan oleh pimpinan, dan kedisiplinan, begitupun dengan fasilitas pendukung pelayanan seperti alat komputer masih sangat kurang, keberadaan pegawai yang bertugas di kantor tersebut masih perlu ditngkatkan kehadiranya, dan tanggapan petugas dalam memberikan pelayanan di kantor
Desa Parigi masih kurang memuaskan bagi masyarakat, masih mengeluh masalah sikap yang apatis, pelayanan yang lambat dari sikap tidak menyenangkan lainnya.

Faktor-faktor yang mempengaruhi kualitas pelayanan publik , dilihat dari factor penghambat, kualitas pelayanan seperti keterampilan dan pengetahuan masih perlu ditingkatkan, ketepatan waktu dalam menyelesaikan pekerjaan yang diberikan oleh pimpinan, dan kedisiplinan. Sedangkan factor yang mendukung kualitas pelayanan aparatur, dari beberapa aparatur desa sudah memperhatikan tugas dan tanggung jawab yang di tugaskan dan kemampuan kerja dalam memenuhi standar dalam proses pelayanannya.

\section{DAFTAR PUSTAKA}

Abidin, Said Zainal. 2004. Kebijakan Publik. Jakarta : Pencah siwah.

Agung Kurniawan. 2005. Transformasi Publik. Jakarta

Hardiyansyah. 2011. Kualitas Pelayanan Publik. Yogyakarta: Gaya Media 
Nasution. 2005. Manajemen Mutu

Terpadu. Bogor : Ghalia Indonesia

Moenir. 2000. Manajemen Pelayanan Publik.Jakarta:Bina Aksara

Poltak Lijan dkk.2006.Reformasi Pelayanan Publik.Jakarta : Pt. Bumi Aksara

Surjadi. 2012.Pengembangan Kinerja Pelayanan Publik.Bandung : PT Rafika Aditama

Sinambella, Lijan Poltak. 2008. Reformasi Pelayanan Publik. Jakarta : Bumi Aksara

Sujardi. 2009. Kinerja Pelayanan Publik. Bandung: Refika Aditama

Sampara Lukman. 2002. Manajemen Kualitas Pelayanan. Jakarta : STIA LAN

Undang-undang No 25 tahun 2009 tentang Pelayanan Publik. 